\title{
TAKE CARE
}

How to be a Great Employer for Working Carers 
David has got his timing just right. With heightened awareness of 'care', this guide will be a landmark publication. It is an extraordinary combination of the personal, the reflective and the practical. I intend to make sure it is in the first red box of every new Minister charged with responsibility for Social Care for years to come! Look hard into this book - for somewhere inside it, is you.

- Rt Hon Alistair Burt MP, Minister for Community and Social Care 2015-16, Co-Chair APPG Carers and President, Carers in Bedfordshire

Caring matters to us all. We are cared for at birth, we care for our children, we care for our parents, and we end up being cared for. Our longer lives means many people need to keep working longer and not drop out because of caring responsibilities. This book bridges the moral case for why carers need support with the business case for doing so. Employers are going to face worsening skills and labour shortages and will need to make it possible for employees who are carers to keep working - just as we have done for women with children. I hope it will be widely read and acted on.

- Geoffrey Filkin, Chair, Centre for Ageing Better

While there are a plethora of resources available internationally to describe the role of carers; not all are written in the absorbing, down-to-earth and readerfriendly way that David has mastered.

- Ara Cresswell, CEO, Carers Australia 
In this short $\&$ very readable book, David shows why and how employers should care for their working Carers. I hope it will also inspire more Carer associations around the world to create equivalents of Employers for Carers, which has had such an influence on policy for carers in the UK.

- Baroness Jill Pitkeathley,

Co-chair All-Party Parliamentary Group on Caring

\{Take Care\} should become required reading for those wishing to understand, introduce and develop great policies and practice for working carers.

- Ian Peters, Chairman Employers for Carers, UK

David has been pushing forward the agenda on responsible business for many years. He is very much doing so again now with Take Care, challenging us to think about how employers can help their working care-givers - and crucially why it makes good business sense to do so.

- Momo MahadavlPresident \& CEO, Maala|Business for Social Responsibility, Israel

We live in an ageing society, so it is critical that people are able to work for as long as they need and want to. Helping workers with caring commitments makes it possible for more of them to stay in work or return to work. David Grayson has produced a compelling case with plenty of practical and successful examples from around the world.

- Andy Briggs, Chief executive officer of Aviva UK Life and Chairman of Global Life \& Government Business Champion for Older Workers 


\section{ABOUT THE BOOK}

Employers large and small need to take care!

They are at risk of losing some of their most valued and valuable employees. They will not lose these employees to competitors or to self-employment but to the employees' loved ones for whom the employees have significant caring responsibilities. The average UK workforce today will have at least one in every nine employees who are juggling their job with caring for a loved one. In Canada, this is $1: 3$. This may be a parent or elderly relative; a partner; a disabled son or daughter or a close friend.

Caring is a natural part of life - it is fundamental to the human condition. Many of us, when we start caring for someone, don't think of ourselves as a 'carer'. We are simply doing what comes naturally as a loving son or daughter, partner, parent. Sometimes, caring can be a short episodic burst - perhaps when a loved one needs help to recover after an operation or is suffering from severe depression. Other voluntary carers may be caring long-term and the amount of their caring progressively increases. Many working carers simply give up on juggling work, caring and personal life and quit their jobs. This can be bad for them (the negative caring nexus: greater financial pressures, greater social isolation, poor physical and mental health); bad for their employers (loss of institutional memory, productivity and of experienced and talented staff); and bad for society as employees with 
caring responsibilities who feel forced to quit their jobs, will have lower pensions and fewer savings to fall back on in later life and will, therefore, be more dependent on the state.

Yet it need not be like this. Smart (as well as responsible) employers understand the business as well as the moral case for helping employees with caring responsibilities to stay in work. Such organisations identify their employee carers, offer flexible and home-working, carerleave, support internal networks of employee carers, provide access to advice and information, and continuously learn and improve, through exchanges with other employers as well as regular feedback from employees. 


\title{
TAKE CARE
}

\section{How to be a Great Employer for Working Carers}

\author{
BY \\ David Grayson
}

\section{emerald PUBLISHING}

United Kingdom - North America - Japan

India - Malaysia - China 
Emerald Publishing Limited

Howard House, Wagon Lane, Bingley BD16 1WA, UK

First edition 2017

Copyright (C) 2017 Emerald Publishing Limited

Reprints and permissions service

Contact: permissions@emeraldinsight.com

No part of this book may be reproduced, stored in a retrieval system, transmitted in any form or by any means electronic, mechanical, photocopying, recording or otherwise without either the prior written permission of the publisher or a licence permitting restricted copying issued in the UK by The Copyright Licensing Agency and in the USA by The Copyright Clearance Center. Any opinions expressed in the chapters are those of the authors. Whilst Emerald makes every effort to ensure the quality and accuracy of its content, Emerald makes no representation implied or otherwise, as to the chapters' suitability and application and disclaims any warranties, express or implied, to their use.

British Library Cataloguing in Publication Data

A catalogue record for this book is available from the British Library

ISBN: 978-1-78714-293-0 (Print)

ISBN: 978-1-78714-292-3 (Online)

ISBN: 978-1-78714-917-5 (Epub)

ISOQAR certified Management System, awarded to Emerald for adherence to Environmental standard 
Dedicated to the memory of Patricia Grayson (1922-2015).

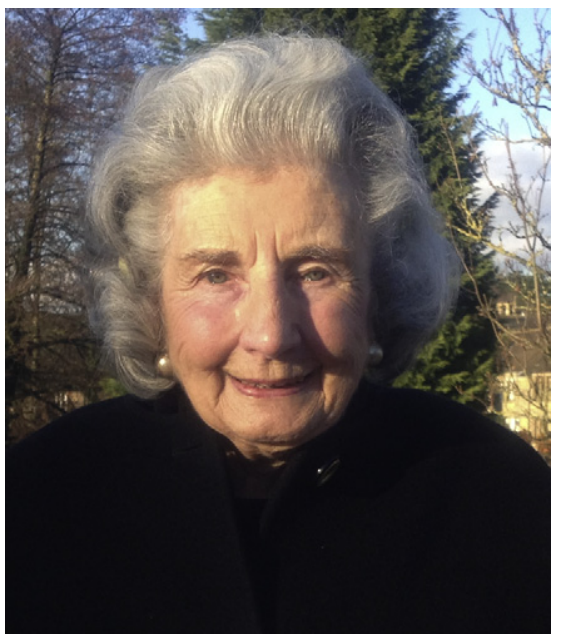




\section{LIST OF DIAGRAMS}

\section{Introduction}

Diagram 1: Caring For Carers: The Missing Jigsaw Piece ... . . . . . . . . . . . . li li

Diagram 2: Theory of Change . . . . . . . . . I I

\section{PART 1, Chapter 1}

Diagram 1: Caring Vicious Circle Nexus Diagram . . 9

Diagram 2: Caring and Working Across the European Union . . . . . . . . . . . . . . . . 13

Diagram 3: Carer Segments . . . . . . . . . . 20 20

\section{PART 1, Chapter 2}

Diagram 1: Caring Journey. . . . . . . . . . . . 22

\section{PART 2}

Diagram 1: Seven Step Framework . . . . . . . . 69

Diagram 2: Triggers Matrix. . . . . . . . . . . . 70

Diagram 3: Blueprint for Better Business Framework . 74

Diagram 4: Unilever Employee Poster . . . . . . . . 126

Diagram 5: London Fire Brigade Carers Portal.. . . . 135

\section{PART 3, Chapter 1}

Diagram 1: Successful Caregiving Technologies

Require Three Supports . . . . . . . . . . . . . . . 184

Diagram 2: Janet Fast Pyramid of Carer Needs. . . . 189 


\section{PART 3, Chapter 3}

Diagram 1: Geting more Employers of Carers - Levers to Influence Change . . . . . . . . . . . . . . 203 


\section{LIST OF PHOTOGRAPHS}

\section{Dedication}

Patricia Grayson $2012 \ldots$. . . . . . . . . ix

\section{Preface}

Helen Johnson and her son Ben . . . . . . . x xxix Introduction

Author with mother $2011 \ldots$. . . . . . . xxxvii

\section{PART 1, Chapter 2}

Nedhal Sahar . . . . . . . . . . . . . 33

James Ashwell . . . . . . . . . . . . . . . . . . $\quad 35$

\section{PART 2}

Craig Hughes . . . . . . . . . . . . . . . . . 93

James Melville-Ross. . . . . . . . . . . . . . . . 96

PART 3, Chapter 1

Geoff Kitchener . . . . . . . . . . . . . . 178 
There are only four kinds of people in the world - those who have been caregivers, those who are currently caregivers, those who will be caregivers and those who will need caregivers.

- Rosalynn Carter, Former First Lady of the USA and founder of The Rosalynn Carter Institute for Caregiving 


\section{FOREWORD BY ARA CRESSWELL}

While there are a plethora of resources available internationally to describe the role of family and friend carers, the pressures upon them, their contribution to both the people they care for and to the wider society and what supports they need to sustain them, not all are written in the absorbing, down-to-earth and reader-friendly way that David has mastered.

While David has canvassed a range of issues relating to the caring role, the focus on combining work and care has particular resonance for an Australian audience.

Several times throughout this publication Australia's good record in recognising both the value and needs of carers is cited. It is indeed true that carers have achieved a high profile accompanied by a more supportive policy environment in the last decade.

The national government and many states have introduced Carers Recognition Acts which formally recognise and value the role of carers, acknowledge that they have their own legitimate needs for support within and beyond their caring role, recognise that they should be regarded as partners in care by medical professions and other service providers which support those they provide care to, and embody charters for carers and place obligations on public service agencies to honour those charters. (Unfortunately the penalties for not observing the admonitions of the Acts are negligible.) 
In 2014 changes were made to the national Fair Work Act 2009 (which sets national employment standards) to recognise an entitlement for unpaid carers of up to 10 days of paid personal/carer's leave which can be accumulated from year to year.

Very importantly, the social security system incorporates a Carer Payment for carers who cannot work because of the demands upon them as carers and who meet a means test. It is roughly the equivalent of the Age Pension and is indexed to average male weekly earnings. In addition, a fortnightly indexed Carer Allowance of AU $\$ 124.75$ is available to assist with the additional costs of caring for carers providing substantial care. Carers on the Carer Payment, Carer Allowance and Veteran's pensions are also eligible for a lump-sum annual payment of $\mathrm{AU}$ \$600. The Carer Allowance and the annual payment are available to carers even if they study or work.

Both the national and state and territory governments also contribute to the costs of providing carer support services. In particular, the focus on carers being able to combine work and care has assumed a very high profile in recent years. The reasons are varied, but for government a particularly compelling reason arises from a preoccupation with the long-term economic cost of social security. The research shows clearly that the longer people stay out of employment because of their caring responsibilities, the less likely they will be able to return to employment when their caring role diminishes or ends. They will very likely simply transition to another, albeit less generous, social welfare payment and, in the absence of their capacity to accumulate superannuation benefits, 
will be reliant on the aged pension when they are past working age.

Persuading employers of the value of recruiting or keeping carers in their employ is a more challenging task. David's book canvasses in detail the case for employers from the perspective of their business interests - including the benefits of keeping experienced employees, reducing the costs of recruitment, the value of a loyal workforce and the benefits of workforce diversity which has become a prominent theme in management and business literature.

Importantly, David highlights that a carer-friendly workplace is not just a matter of employers taking on carers or keeping them on where they acquire caring responsibilities or the caring role intensifies. As a number of carer stories in this book highlight, the understanding and support of managers and co-workers is particularly important. This means that a truly carer friendly workplace makes the effort to educate all its employers about the role of carers, not just the human resources parts of the enterprise.

A workplace which values carers and wishes to assist them to combine work and care will also make information available about where carers can get support and services outside the workplace.

David has identified a range of strategies, models and case studies for creating carer friendly workplaces which will be of great assistance in the campaign to capture the hearts, minds and hip pocket nerve of employers and foster a commitment to assist their employees to combine work and care.

Ara Cresswell CEO Carers Australia 


\section{FOREWORD BY IAN PETERS}

'No one should need to care alone'. This rallying cry from Carers UK's 50th anniversary campaign should equally apply to those who juggle work and caring responsibilities. However, employers' attitudes towards working carers generally significantly lag that for parents with children.

I have known David Grayson for over 20 years in various capacities, most recently as colleagues on the board of Carers UK. It is entirely consistent with David's long held conviction that employers can be forces for good, that his personal experiences of caring so articulated in this book, have led him to what should become required reading for those wishing to understand, introduce and develop great policies and practice for working carers.

In his own words, this book is a cross between a how to guide and a call to action'. David lays out a seven step approach from discovering the need through to monitoring the effectiveness of policies. I confess that as the former leader of a large organisation quoted by David as an exemplar in this field, we felt our way there by listening and acting. This blueprint would have been really helpful 10 years ago!

David brilliantly combines the power of individual stories with a deep insight into worldwide analysis of what has worked, what has failed, the challenges and opportunities. From Helen at Westpac in the preface, to 
his own story, to Craig Hughes and James Melville-Ross as exemplar leaders, the stories drive home his insights in a compelling and memorable way.

Demographics in the developed world make it clear why this book should be read by multiple audiences from business leaders, to HR professionals, academics to policy makers. Caring is becoming a universal human experience. In the United Kingdom 1 in 9 employees are carers, with that rising to 1 in 6 for those aged 45-64. By 2030 that will be 1 in 6 and 1 in 3 - a figure already reached in Canada. Once an employee spends 5 hours per week caring, it impacts their work, health and often earnings potential. Without the necessary empathy, information, flexibility and support far too many leave the workplace.

Retaining that experience, returning former carers to the workplace, and recruiting young carers makes good business sense. It is not corporate philanthropy.

There is no single template on what will work for every organisation, but the book highlights three common pillars: leadership by example; supportive and empowered line management; flexibility to changing individual circumstances.

David lays out many examples of great practice, which are often set in a wider context of a commitment to diversity, inclusivity and corporate responsibility. He highlights the opportunities created by existing and emerging technologies to redefine both support for working carers and also new forms of self-employment and collaborative enterprise for those combining work and care.

He shows how non-UK countries now lead the way in carers leave, with France and Belgium using fiscal incentives to grow local support businesses. 
The book is uplifting but also sobering. While much has been done by many enlightened companies and governments, much remains to be done. Adoption is hugely variable; SMEs are largely not yet engaged; employers cannot fully address the issue without high quality local care provision and supportive public policy; too many organisations have 'hidden carers' concerned about the perceived adverse impacts of declaring they are carers.

David admits to being an optimist and a campaigner. Encouragingly he has a track record of success. This book will increase the probability of success in this area.

In my capacity as Chair of Employers for Carers (EfC) in the United Kingdom, the only self-financing employer led carers group in the world, I share David's aims and optimism. EfC has built a membership base representing over 1.25 million employees and an easily accessible compendium of best policy and practice. We have doubled our membership in 3 years as awareness grows, and we now sit at the table of government policy.

The provision of excellent workplace support for carers is a fourfold win: for the carer; for the employer; for the wider economy through higher tax and lower benefits; and importantly for the person being cared for.

David's book should help accelerate the momentum and I commend him for his initiative and passion.

Ian Peters Chairman Employers For Carers 


\section{PREFACE}

Work: the chance to be me!

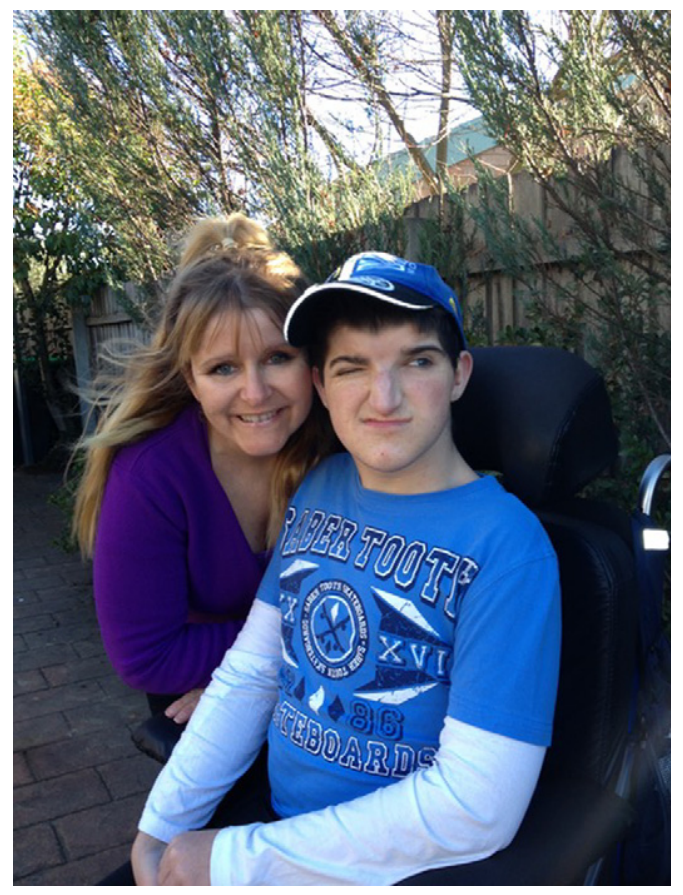

"It's not just a question of the money. It's the opportunity to use my experience and skills, to contribute to my workplace and community, and to enjoy some social life among a wonderful group of supportive colleagues. Very importantly, it gives me the chance to be just me, "Helen" the person, as well as the loving mother and carer of Ben." 
Together with her husband Peter, Helen Johnson has cared for her profoundly disabled 24-year-old son Ben since his birth. Ben was diagnosed with Rubinstein-Taybi Syndrome (RTS) at birth and has a severe intellectual disability, medical, physical and sensory complications due to a further diagnosis of Autism Spectrum Disorder at 3 years of age.

Sadly, Ben also became a paraplegic in 2009 after an 'unexplained' postoperative complication causing an 'incomplete spinal cord injury'. To date Ben has had to endure 54 surgical procedures all in Melbourne, $180 \mathrm{~km}$ from the family home in the Australian state of Victoria.

The Johnson family has faced intense financial and emotional distress. In addition to Ben needing 24-hour care, his disabilities have come with enormous medical, specialised equipment and other associated costs. Helen says caring is a 'tough job'.

'It is financially restraining, emotionally stressful and complex... so much goes into organising your own life and someone else's as well'.

When Helen gave birth to Ben, her employer - the Australian bank Westpac Banking Corporation - gave her as much 'Carers Leave' as required.

However, when Ben was 3 years of age, 'I could not envisage my ability to return to work due to his chronic illness and the 24/7 care needs I was required to provide therefore, I sadly resigned from Westpac in 1996'.

In 2003 an ex bank manager opened her own Financial Broker Service and asked Helen to join her on a casual basis, even though Helen continued to need a great deal of time off due to Ben's medical needs and health challenges. 
'However, after 12 months a particular Westpac Manager heard I had returned to work and approached me to return to Westpac on a casual or part-time basis. Of course I jumped at the chance, and returned as a casual employee with the agreement of $100 \%$ work flexibility, as Ben was, and continues to be, my number one priority. I continue to be employed with Westpac to this day but I have now obtained a permanent part-time position with an on-going agreement and permission to have work flexibility to support Ben whenever required'.

Helen has received the full support of her workplace managers and colleagues at Traralgon and now Morwell Westpac branches in Victoria, which has enabled her to work part-time while still attending to Ben's immediate needs, countless visits to specialists and frequent surgeries

'My wonderful Managers and work colleagues continually provide me with amazing flexibility and understanding with my arrival times in the morning as often I don't know what to expect each morning when entering Ben's room to help prepare and get him ready for the day.

Firstly, you would not believe the enormously long medical regime we have to go through for Ben, however when the 'odd' surprise is thrown in with the "everyday" stuff that's when it is NOT a GOOD START TO THE DAY!

Some mornings (or in the late hours of the night or early hours of the morning) I would enter his room and it would be like a murder scene because he has put his fingers so far up his nose (he loves holes) that he would have a continual blood nose and he would smear blood everywhere! 
However, it is a really bad morning (or night) when I enter his room and I discover he has managed to dislodge his continence pad and managed to smear faeces over every part of his body, in his mouth, in his ears, up his nose, in his hair and all over his bed. This is why I am required to do 2 to 3 hourly night checks on him every night and we also have to ensure his catheter is flowing and not blocked and that he is comfortable due to his minimal ability to move and re-position his body.

It is also not unusual for him to have a small vomit in the night and of course because he cannot call out to us, he just has his little "silent vomit" makes sure he can smear a majority of it over every part of bed and himself and then quietly lays his head straight back down and continues to snore! He truly is a placid young man'.

\section{THE IMPORTANCE OF WORK IN THE CARING JOURNEY}

As Helen says: 'It's not just a question of the money. It's the opportunity to use my experience and skills, to contribute to my workplace and community, and to enjoy some social life among a wonderful group of supportive colleagues. Very importantly, it gives me the chance to be just me, "Helen" the person, as well as the loving mother and carer of Ben'.

'Although my job in the bank is demanding I continually say, I go to work for my sanity and for my "respite". My work life helps me keep sane! I know I would not be the person I am today, without my employment. I also believe without my work, my own emotional mental 
health and well-being would be challenged. It gives me the necessary social opportunities and connections. Working gives me a meaningful purpose, separate from my intense caring role. It gives me my own independence, enables me to contribute financially towards my family's needs and helps create financial sustainability for our future'.

What did it feel like when Helen gave up work to care full-time for Ben?

'I felt emotionally devastated, ripped off and extremely sad. I felt we were financially crippled because we had just built a house based on having two salaries. I felt very low, as if life had been pulled out from under me. Everything I had worked so hard for, I felt I had lost all my dreams. I had so many fears. What use will I be to my family, to both my sons but especially my son with severe and multiple disabilities? How will I manage to care for him when I know nothing?'

Helen is very honest about the mental health issues she encountered and how much she benefitted from a counsellor whose own son had been severely injured in a driveway accident from a car. 'She showed me that my feelings were ok and normal and that I can and will get through this'.

\section{HOW EMPLOYER SUPPORT MAKES A DIFFERENCE}

'I am so proud to have Westpac as my employer as it truly is supportive to its employees and especially to those who are carers. Another example is when an employee is applying for Annual Leave; on the electronic leave request 
it has a question, 'Are you applying for annual leave to care for someone or for medical reasons?' Also some of the Westpac Employee Perspective Surveys asks the Question: Are you a Carer? Do you Care for somebody? I think these questions are an example of a sincere, carerfocussed company who truly cares about its employees and their overall health and wellbeing. My managers, work colleagues \& Westpac (as an employer) have been SO supportive to me as an unpaid family carer and to my family situation with regular reminders that 'family comes first' and 'family life work balance'. I am forever grateful for their amazing on-going support'.

Twenty plus years on and you don't need to speak to Helen for very long, before realising she is a great example of the old adage that if you want something doing, ask a busy person!' Besides caring for Ben and working for Westpac, Helen also works two days a week at a State-wide Disability Support Service in Melbourne as a Parent Support Worker and an NDIS Education Facilitator. This workplace is $360 \mathrm{~km}$ round trip from home requiring an early start and would not be possible without the support of her husband (Ben's father) Peter, as he also engages in flexible Carer work hours to enable Helen to leave early in the mornings.

Helen is also a National Carer Ambassador for Carers Australia and in 2015 received a Nomination for 'Australian of the Year' and although she did not win she said it was an absolute honour to have received this National recognition for her passion and dedication in advocating for and on behalf of Carers across Australia. She also sits on a number of federal government consultative committees for carers and disability, which meet in 
Canberra. Helen is also a Volunteer Board Member for a local Gippsland Disability Service Provider Interchange Gippsland and a Volunteer Board Director for Carers Victoria which is a State-wide Carer Service. She has served on both Boards for over 10 years and she is currently the Vice President of both organisations. Also, Helen recently received a Life Membership to Carers Victoria for her passion and ongoing commitment to creating positive change for Carers throughout Victoria and Australia.

Her advice to other carers? 'Never say never! I thought it would be impossible to return to work after Ben was born. Be honest with your employer: I know some people choose not to talk about home life and their personal caring situation - especially men - but if possible, it is important to do so, because employers can't assist and support you if they don't know of your caring responsibilities. Many more employers are attempting to support their employees who are family Carers but it has to be a two-way street and I believe good communication with your Manager's and Work Colleagues is the key. If possible, whilst on Carers Leave, keep connected with your employer: sometimes it is hard to think beyond your caring role but it is important to ensure a smooth transition back to work when it is possible to do so!'

Despite being an intensive, long-term carer, Helen can also work because she has an employer that strives to be a great employer for working carers, she has supportive line-managers, understanding co-workers, customers who want to be served by Helen because of her empathy and vitality, employer policies for flexible working, carer leave, a relevant EAP (Employee Assistance Programme) 
and above all - a co-determination to make the arrangement work.

Take Care is about how to ensure that many more people juggling work and looking after a loved one, can do so successfully and positively. 


\section{INTRODUCTION}

\section{WORKING AND CARING: THIS IS PERSONAL}

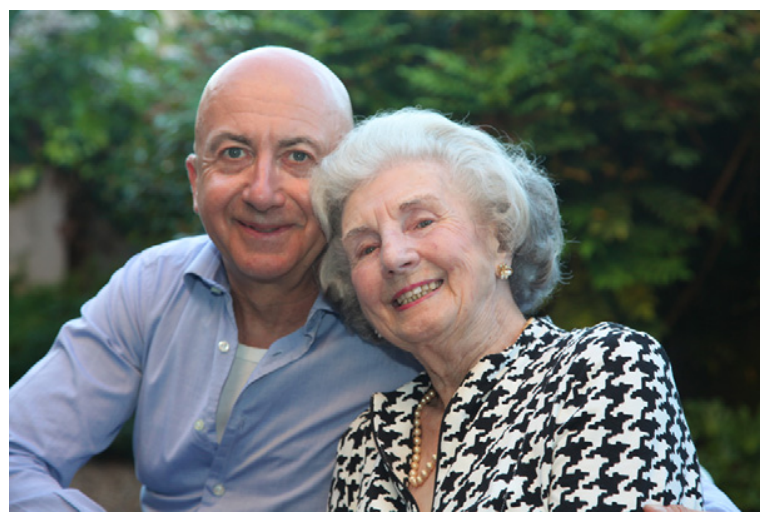

Photo courtesy of Michael Holt.

This book is dedicated to my mother Patricia Grayson (1922-2015).

She is the reason why I have written this book.

Mum was a primary-school teacher for almost 40 years. She graduated with distinction from Edgehill Teaching College in 1942. Apart from one term teaching in York, all the schools she taught at were in Sheffield and subsequently in North East Derbyshire. Her early classes in the Darnall and Attercliffe areas of Sheffield in the later years of World War II and immediately 
afterwards had more than 60 pupils. On a very conservative estimate, given the much larger class sizes she faced in the early years of her career, there were more than 1500 people whose early years of schooling were at the hands of mum.

A couple of days before mum died, Louise - the student nurse who accompanied the district nurse for much of mum's final, palliative care at home - arrived with some additional medication. She had collected it from a local pharmacy and was keen to report the exchange she had just had with the lady handing over the medication:

'It is for Mrs Grayson? She taught me. She was the best teacher I ever had!'

As mum's neighbour Pauline also discovered over the years, that was not an unusual experience. In doctors' waiting rooms, at bus-stops, in shops and restaurants, there would be a familiar routine. Someone would look over, nervously smile and finally approach mum with a similar message of gratitude and appreciation.

As Dame Julia Cleverdon wrote after mum's death:

'Your mother influenced generations to step up to their responsibilities - to give more and get more from their lives.'

Mum's gift for engaging young children never left her. Penny Hawley described bringing her two young sons Hew and Eddy on several Christmas visits to South Ridge towards the end of mum's life:

'As you might have gathered from my questions at the time, I was worried about bringing the boys along to meet her, because most of us age more in our ideas and attitudes than our bodies and struggle to remember why small children are curious and inconvenient. Not the 
marvellous Mrs Grayson who welcomed us all and clearly delighted in chatting with Hew about iPads and the other things he was interested in. She had such warmth and enthusiasm that she captivated us all. The inspiration she must have been to the hundreds of children who passed through her classroom shone through'.

Shortly before her 90th birthday, I encouraged mum to write down a list of some of her happiest moments. As might be anticipated, many of the moments involved the family but several of the happiest memories that she had listed first were about things in her teaching career. I believe mum was a great teacher because she genuinely cared for and was always interested in people. As her great-nephew Sam wrote on her 90th birthday poster: 'she lit up the room' and as he wrote on hearing of her death: 'she made you feel so loved whenever she saw you'.

In similar vein, her great-niece Caroline wrote: 'she always remembered every detail of what I was up to! She was a fantastic lady ... and like a fifth grandparent'.

Mum and I always enjoyed a close and loving relationship, as only children in particular usually do with their parents. On my 11th birthday, she and my late father had to rush me into Sheffield Children's Hospital. What the local GP had days earlier diagnosed as a sprained knee was actually a rare and life-threatening bone disease in the hip: osteomyelitis, complicated by septicaemia. I was critically ill. For several days, it was touch and go whether I would live or die. Subsequently, the specialists suggested that if I lived, my parents might have to face the prospect that I would not walk again. Happily, the medics exaggerated. It was, however, to be a year before 
I did walk again - on crutches and several years before I could walk unaided. Meantime, I had my left hip removed and I spent many months in a hip-spiker (a plaster of Paris casing from my upper chest to my toes with strategically placed holes) whilst my leg, minus hip, fused in the hip-socket. Throughout this time, my mum never missed a day's hospital visiting. Whenever it was possible, mum nursed me at home, giving up her teaching job to do so. At the age when children are learning to grow more independent of their parents, I became entirely dependent again on mine - and especially my mother to take care of my bodily functions, feed me, keep me distracted, reassure me. Mum didn't just care for me physically. She also helped me to deal with the "why is this happening to me? If there is a God, why is He doing this to me?' despair and anger. Mum subsequently returned to teaching, in substantial part to pay for me to go to a good school and then to Cambridge - the first person in my family to go to university. Mum subsequently took early retirement from teaching to care for her mother at home. In time, she also cared for her best friend and then became carer for my father in his final years.

\section{Becoming Mum's Carer}

So, decades after mum nursed me through the osteomyelitis, when first dad and then my mum started to need more help, it just seemed the natural thing to try and do my very imperfect best to help them and support them. Caring for loved ones after all is part of the human condition, part of what it is to be fully human, part of the 
natural rhythm of life, as the quotation from Rosalynn Carter reminds us. I certainly didn't think of myself as a 'carer' - just a son helping his parents and looking after them. In all likelihood, I would have continued as a 'hidden' or non-self-identifying carer, but for Helena Herklots. Helena and I had previously served together for 5 years, on the board of a major social enterprise providing sheltered housing and domiciliary paid care for older people. Helena had often heard me at board meetings, ask whether I would accept something being proposed for clients, if it was for my own parents, in evaluating proposals. Shortly after she became CEO of the charity Carers UK, Helena got in touch again and invited me for a coffee. When we met, she quietly explained that at any one time in the United Kingdom, 6.5 million Britons are caring unpaid for a loved one - and that Carers UK is there to help and support these carers. Then she dropped the bait! 'Many people don't think of themselves or identify as a carer'. She paused. I smiled. I took the bait! Three months later I joined the board of Carers UK. Fastforward another year and I became chairman as the charity was gearing up for its fiftieth anniversary.

\section{LEARNING HOW EMPLOYERS HELP CARERS JUGGLING JOBS AND CARING}

I quickly discovered that many care-givers are juggling their job and their caring responsibilities; and that one of the initiatives of Carers UK is Employers for Carers - an alliance of employers including British Gas, BT, KPMG, Sainsbury, the Metropolitan Police and others - who 
aspire to be great employers of care-givers. I am passionate about the work of Carers UK. Like the rest of my board and staff colleagues, I want to see a society which respects, values and supports carers. I want an end to carer isolation. No one should have to care alone. Given how many people are working and caring, reaching carers through their employers is one very important channel of communication. Supportive employers can help many carers to stay in work. Where that is possible, it is good for the employer, for the carer - and for the person being cared for and the rest of their family both short term and for the future. I have a particular interest in this. I went half-time in my own job at Cranfield University School of Management, with a consequent $50 \%$ drop in salary and knock-on impact on pension pot, in order to help look after mum in her final couple of years. I don't regret that for a single moment.

\section{Becoming Mum's Carer}

Despite all my previous experience and networks, I still struggled as a carer. My fitness routine was gradually abandoned. Progressively, I stopped accepting invitations to functions that weren't immediately necessary to my current work. Socialising declined. Anecdotal conversations with other carers, as well as research carried out by and for several of the carers' associations around the world, suggest my experience is very common. As one very successful executive with a top global company, who had quit her job to care for her mother, said to me: 'if you and I were struggling, as well-connected, reasonably 
well-off people, how much tougher is it for anyone with fewer friends and contacts or in a less fortunate material situation?' Her question has driven me on to complete this book.

I want to see a society which respects, values and supports carers. I want an end to carer isolation. No one should have to care alone.

More and more of us will be juggling work and looking after a loved one. I vividly recall walking through Oxford one Spring evening, several years ago. I was attending the Skoll World Forum on Social Enterprise. I was walking between events with an old friend and mentor Prof Kirk Hanson from California. Kirk is one of the world's leading business ethicists. I interrupted our conversation in order to make my nightly phone call to mum. I tried to make it the same time, 6 p.m., each night no matter where in the world I was. Kirk patiently waited for me to finish the call and then quietly commented: 'that is part of my next book!' I was confused. 'I thought your next book was about ethical dilemmas every manager will face?' I replied. 'It is', Kirk explained, 'and looking after elderly parents alongside your work is very much one of those!'

I was very fortunate. I could afford to take a $50 \%$ salary cut. Mum had wonderful neighbours: Jim and Pauline Harling, who popped across to see her every day and would alert me if anything untoward had happened when I was not there. I drastically reduced my overseas travel for work. When I did go abroad, we started to experiment with different respite care homes. Invariably, when I returned and collected mum, the home unprompted - would say what a delight mum had been 
to look after; and they would be very pleased if she would like to stay. Mum, whilst unfailingly polite and appreciative to the care home staff, was always keen to get home. Although we did discuss different care options, I knew mum wanted to stay in her own home, if she possibly could - so that was my mission.

Eventually, mum needed 24/7 live-in care. Thanks to a chance introduction from a work colleague, I was connected to a small business Miracle Workers specialising in placing live-in professional care workers with clients. We were incredibly fortunate in meeting Ann Luff who looked after mum for most of her final 13 months. Ann's loving and calm presence lifted a great deal of the stress from me. I still made the $520 \mathrm{~km}$ round-trip from my home in London to Sheffield and back most weeks, but instead of food shopping and other domestic chores, it could be more about being a son, going through old photographs together, going out for meals and trips into Derbyshire, and reading poems and prayers.

My work on Take Care had a three-month hiatus when mum went in to a final, precipitate decline. I had always dreaded that I might be abroad for work and unable to get back in time. As it was, I realised mum was deteriorating, returned to Sheffield and then abandoned my return to London for meetings. It was good that I did. I was up all night with mum. The next morning, her long-standing GP who had only visited the day before, came back again and after examining mum, broke the news that she thought mum was dying. We both knew mum's wishes were to die at home. With the help of Ann, Jim and Pauline and wonderful district nurses, we were able to fulfil mum's wishes. My bedside vigil lasted 
11 days and nights. Work colleagues were understanding and covered for me. It never occurred to me that my employer would be unsympathetic; but nor was I aware of formal policies for such circumstances. I simply intuited from my inchoate sense of the university culture. In truth, wild horses would not have dragged me away from mum, but it was still reassuring to feel the empathy and understanding of colleagues and employer. Once I did return to work some weeks after mum's death, I started to think not just about resuming work on Take Care, but also about how the university might turn informal custom and practice into a more structured Carers' Policy. My subsequent work on this book has, therefore, gone in parallel with some 'gentle nudging' (I am from Yorkshire remember!) of the University, as I will explain later on.

Looking after my mum in her later years, ensuring she could stay happily and safely in her own home and always have things to look forward to is the most important thing I have done in life and I imagine will remain so. I suspect a bereavement counsellor might consider, in some small way, Take Care, as my personal equivalent of ' $\mathrm{H}$ is for Hawk' - the acclaimed memoir of Helen Macdonald - a grief-stricken daughter who became obsessed with training a goshawk following her father's death, which won the Costa book of the year in 2015.

\section{ABOUT TAKE CARE}

The book is written to be read straight through. However, for the time-pressed readers, there is an 
overview at the start of each section, and key take-aways at the end of each section. There are profiles of nearly 50 different employers and how they help working carers, spread through the text (see the box below).

\begin{tabular}{|c|c|c|c|}
\hline $3 \mathrm{M}$ & Multinational conglomerate & US & 123 \\
\hline AbbVie & Pharmaceuticals & Israel & 72 \\
\hline Accenture & Consulting & UK & 140 \\
\hline Ajinomoto Group & Food & Japan & 111 \\
\hline $\begin{array}{l}\text { Associe } \\
\text { International Inc }\end{array}$ & & UK & 161 \\
\hline Astellas & Pharmaceuticals & Japan & 125 \\
\hline $\begin{array}{l}\text { Australian Bureau } \\
\text { of Statistics }\end{array}$ & Government & Australia & 140 \\
\hline Aviva Life & Insurance & UK & 87 \\
\hline Be Inspired Films & Film-making & UK & 159 \\
\hline BT & Telecommunications & $\begin{array}{l}\text { UKJ } \\
\text { international }\end{array}$ & 118 \\
\hline Carnstone & Consultancy & UK & 157 \\
\hline CBI Health Group & Health \& care & Canada & 33 \\
\hline Centrica & Energy & $\begin{array}{l}\text { UK/North } \\
\text { America }\end{array}$ & 173 \\
\hline Cranfield University & Higher education & UK & 236 \\
\hline Credit Suisse & Financial services & $\begin{array}{l}\text { UK/ } \\
\text { international }\end{array}$ & 143 \\
\hline $\begin{array}{l}\text { Deloitte, } \\
\text { accountancy \& } \\
\text { consultancy }\end{array}$ & & Ireland & 125 \\
\hline Emory University & Higher education & USA & 125 \\
\hline Fannie Mae & Financial services & USA & 126 \\
\hline FTI Consulting & Corporate communications & UK & 99 \\
\hline Grosser Cleaning & Domestic services & Germany & 160 \\
\hline GSK & Pharmaceuticals & international & 112 \\
\hline Happy Consulting & Workplace well-being & UK & 160 \\
\hline
\end{tabular}




\begin{tabular}{|c|c|c|c|}
\hline Harvard University & Higher education & USA & 124 \\
\hline Hyde Housing & Social housing & UK & 112 \\
\hline IBM & $\begin{array}{l}\text { Multinational technology and } \\
\text { consulting }\end{array}$ & & 39 \\
\hline J\&J & Pharmaceuticals & $\begin{array}{l}\text { USA/ } \\
\text { international }\end{array}$ & 88 \\
\hline $\begin{array}{l}\text { Johns Hopkins } \\
\text { University }\end{array}$ & Higher education & USA & 83 \\
\hline Listawood & Manufacturing & UK & 157 \\
\hline $\begin{array}{l}\text { Lloyds Banking } \\
\text { Group }\end{array}$ & Financial services & UK & 133 \\
\hline $\begin{array}{l}\text { London Fire } \\
\text { Brigade }\end{array}$ & Public sector & UK & 135 \\
\hline Metropolitan Police & Public sector & UK & 82 \\
\hline Ministry of Justice & Public sector & UK & 109 \\
\hline Mitsubishi & & Japan & 111 \\
\hline Network Rail & Transport infrastructure & UK & 75 \\
\hline $\begin{array}{l}\text { NHS Education } \\
\text { Scotland }\end{array}$ & & & 80 \\
\hline Otsuka & Pharmaceuticals & Japan & 115 \\
\hline PWC & Accountancy \& consulting & $\begin{array}{l}\text { Australia/ } \\
\text { international }\end{array}$ & 93 \\
\hline Pukka Herbs & Food & UK & 159 \\
\hline Sainsbury's & Retailing & UK & 116 \\
\hline $\begin{array}{l}\text { Scottish Courts \& } \\
\text { tribunal Service }\end{array}$ & Public sector & UK & 136 \\
\hline Standard Life & Insurance & UK & 147 \\
\hline Taisei & Construction & Japan & 125 \\
\hline Thyssen Krupp & Engineering/manufacturing & $\begin{array}{l}\text { Germany/ } \\
\text { international }\end{array}$ & 112 \\
\hline Unforgettable & Care & UK & 161 \\
\hline Unilever & FMCG & $\begin{array}{l}\text { UK/ } \\
\text { international }\end{array}$ & 125 \\
\hline
\end{tabular}




\begin{tabular}{|c|c|c|c|}
\hline Unipart & $\begin{array}{l}\text { Logistics, supply chain, } \\
\text { manufacturing and } \\
\text { consultancy }\end{array}$ & $\begin{array}{l}\text { UK/ } \\
\text { international }\end{array}$ & 128 \\
\hline Westpac & Financial services & $\begin{array}{l}\text { Australia/ } \\
\text { international }\end{array}$ & 113 \\
\hline $\begin{array}{l}\text { West } \\
\text { Dunbartonshire } \\
\text { Council }\end{array}$ & Public sector & UK & 110 \\
\hline Wheatley Group & $\begin{array}{l}\text { Social housing, community } \\
\text { regeneration \& care }\end{array}$ & Scotland & 134 \\
\hline
\end{tabular}

\section{WHO SHOULD READ THIS BOOK?}

Ambitiously, I have a number of target audiences for this book: employers, consultants, carer organisations around the world, Workplace Specialists in Business Representative Organisations, Business Development Organisations, Corporate Responsibility Coalitions and Work-Related Think-Tanks around the world, HR academics and professional associations and Governments. This is a diverse group but what they have in common is that they, like me, care about caring. And each organisation can take specific actions to improve its quality.

1. Employers

- HR directors

- Finance Directors/Chief Finance Officers - this is a bottom-line issue

- heads of Diversity \& Inclusion / team members

- Corporate Responsibility / Sustainability directors 
Desired action: Establish a carer policy if you don't yet have one; or review and improve if your organisation already provides some support for carers. Become part of a campaign to engage more employers.

2. Consultants in

- Talent management and Human Resources

- Diversity \& Inclusion (D\&I)

- Corporate Responsibility and Sustainability

- Work-life balance/Great Place to Work

- EAP (Employee Assistance Programme) specialist providers

Desired action: Add carer issues to your agenda with clients if caring for carers is not already included; or review and improve if you already have some support for carers in your agenda/offering to clients

3. Carer Advocacy and Support Organisations around the World

Desired action: Consider adding working and caring to your activities e.g. creating an Employer for Carers type initiative

4. Workplace Specialists inside Business Representative Organisations, Business Development Organisations, Corporate Responsibility Coalitions and Work-Related Think-Tanks around the World

Desired action: Add work and caring to your activities e.g. create an Employer for Carers type initiative in collaboration with your local carers organisations 
5. Academics Specialising in Caring, Business School International Human Resource Management Faculty and HR Professional Associations (EG CIPD, SHRM)

Desired action: Develop the case for why employers should care for their employee carers, research emergent employer practice, and add supporting work and caring to your professional guidance and International Human Resource Management (IHRM) courses.

6. Governments and would-be Governments

Desired action: Politicians responsible for finance, work and pensions, social affairs and health and government ministries covering these topics. Besides an important role as employers of many working carers, a range of government policies and initiatives can support employers to care for working carers - or conversely make employer efforts less impactful.

\section{UNDERSTANDING SUPPORT FOR WORKING CARERS AS A CORPORATE RESPONSIBILITY ISSUE}

My friends and colleagues say I am an inveterate networker and connector (some of them say any encounter with me usually leads to some commitment on their part to do something/meet someone etc.!). It is certainly true that I have been a campaigner since before my childhood illness. I do like to spot and make connections for positive impact. In this case, there is a very obvious connection between my day job: as professor of Corporate 
Responsibility at Cranfield University School of Management and my volunteering with Carers UK.

Corporate Responsibility is the responsibility which an organisation has for its Social, Environmental \& Economic (SEE) impacts. A key part of corporate responsibility is the impact in the workplace: being a responsible employer - and ideally being a great employer.

Caring for working carers is like the missing jigsaw piece for several critical organisational strategies (Diagram 1). These include:

- creating a diverse and inclusive workplace

- talent attraction, retention and optimisation, especially in the context of an ageing workforce

- being a responsible employer

Diagram 1: Caring For Carers: The Missing Jigsaw Piece.

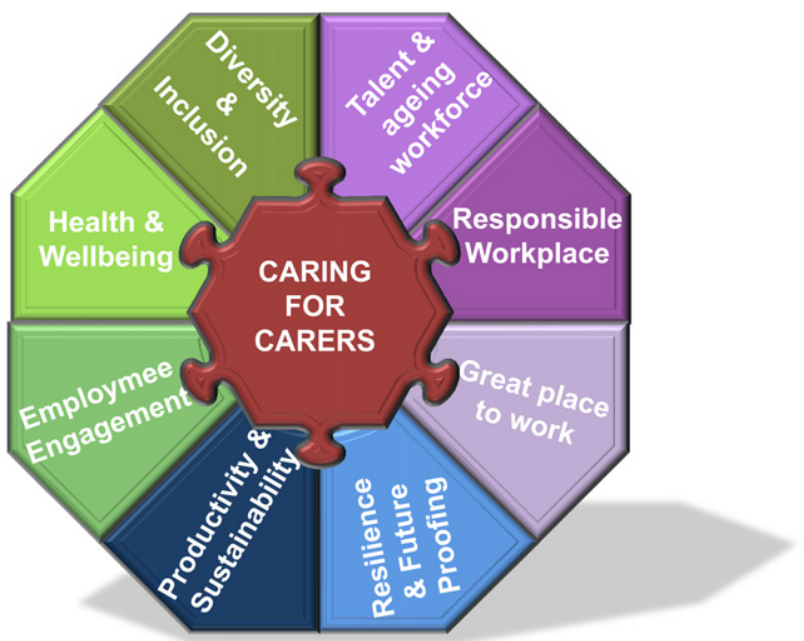


- boosting health and well-being in the workplace and especially, helping to tackle the taboo and stigma of mental ill-health

- being a great place to work

- building employee engagement and advocacy

- sustainably improving profitability through reducing costs and raising productivity

- building organisational resilience and future-proofing.

In a previous role as the first chairman of the UK's National Disability Council (NDC) from 1995 to 2000 (appointed by Parliament to work to end discrimination against disabled Britons), I saw at first-hand how organisations could adapt and develop to become responsible employers of those of us with a disability.

Coming in to Carers UK, it felt like employers of carers were where employers of disabled people had been twenty years ago, in terms of being integrated within mainstream workplace responsible business policies and practices. Back in 1996 when I started as the first chairman of the NDC, I persuaded KPMG to do some pro-bono work looking at the major Corporate Responsibility coalitions internationally. KPMG found that these coalitions were largely silent then on disability issues. A quick trawl of the websites of the major coalitions in 2016 showed them largely silent about employment and caring. Yet as societies age around the world, and as public expenditures come under increasing pressure, how employers can enable their employees to stay in work and simultaneously be effective carers is becoming a global issue. Since I started work on 
Take Care, I have learnt of interest in Australia, Canada, Israel, New Zealand and Sweden to help employers be better at supporting their employee caregivers. My goal is that this book will inspire and help business organisations, Corporate Responsibility coalitions, carer associations, individual employers and social entrepreneurs, to champion caring for carers - and also provide practical guidance to individual employers around the world.

\section{HOW THIS BOOK IS ORGANISED}

In Part $1, \mathrm{I}$ argue that looking after a loved one is part of what it is to be human: caring is deeply ingrained in faith and philosophical traditions; and that caring will affect most of us at different points in our lives. I look at the Caring Journey and explain why employers and society needs to support better those who are working carers.

Synthesising my knowledge and experience of both corporate responsibility and caring, in Part 2, I set out a Seven Step framework - drawn from my book coauthored with Adrian Hodges, Corporate Social Opportunity - which responsible employers can follow to improve their support for working carers for the benefit of their businesses, as well as the carers they employ. I also show that even small employers can care for their carers.

In Part 3 Chapter 1, I describe how organisations can develop their operational practices even further, reaching the highest stages of corporate responsibility "maturity" 
to become "Champion" employers in their support for carers. In Part 3 Chapter 2, I consider how to support carers who are working as freelancers. In Part 3 Chapter 3, I suggest how governments and a range of other organisations and networks can build an enabling environment for more employers to take care of their working carers.

\section{A THEORY OF CHANGE TO BUILD A SOCIETY THAT RESPECTS, VALUES AND SUPPORTS CARERS}

Carers UK has benefitted greatly from a collaboration with NESTA, the independent innovation foundation. NESTA puts a strong emphasis on supporting its partners to articulate a Theory of Change, that they are going to put into practice. A Theory of Change:

explains how a programme has an impact on its beneficiaries. It outlines all the things that a programme does for of its beneficiaries, the ultimate impact that it aims to have on them, and all the separate outcomes that lead or contribute to that impact.

This has inspired me to consider my Theory of Change for Take Care and the international movement I hope we can unleash. The model is adapted and internationalised from the emerging Theory of Change of Employers for Carers (see Diagram 2).

I discuss how we can collaborate to implement the Theory of Change in my conclusion. 
Diagram 2: Theory of Change.

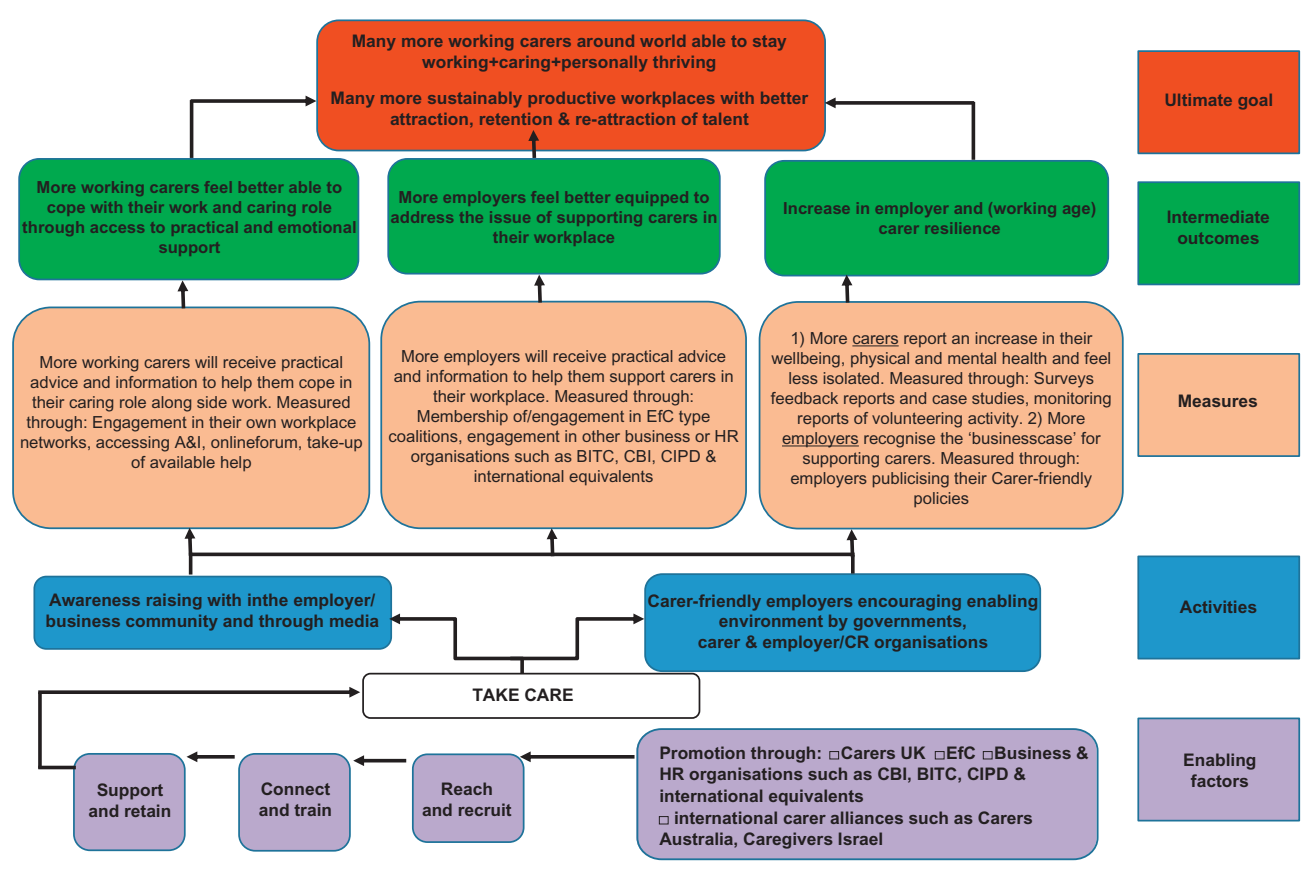




\section{WANTED: COMMITTED CITIZENS TO CHANGE THE WORLD}

One thing that has powerfully resonated with me as I have researched and written Take Care, is the role of individual champions at all levels of organisations. Their stories are interspersed throughout the text. If ever I needed reminding of the famous observation of the late Margaret Mead: 'Never doubt that a small group of thoughtful, committed, citizens can change the world. Indeed, it is the only thing that ever has', my experience of the men and women I have interviewed and whose stories are told in the following pages, has done so. We need more of these 'committed citizens' - champions of carers in the workplace - to 'come out', tell their own stories and promote better help for working carers in individual workplaces and in wider society.

My hope is that, working in collaboration with responsible businesses and other partners, we can make support for working carers 'business as usual'. Many employers are already responding to the expectations and needs of more diverse, multi-generational workforces, with more customised work options. These can be easily stretched and adapted to meet the needs of working carers.

And yes, mum was pretty chuffed that she inspired this book! 


\section{DISCLAIMER}

I am chairman of Carers UK. All royalties from Take Care will go directly to Carers UK. I am deeply indebted to various colleagues in Carers UK for their help and advice as I researched and wrote Take Care - see acknowledgements. I very much hope that I have done justice to the experience and insights of Carers UK and our supporters; and also those of colleagues in a number of carer organisations around the world. Nevertheless, the views expressed in Take Care are my own and should not be assumed necessarily to represent the views of Carers UK. 